\title{
Water use and crop coefficient of subsurface drip-irrigated lettuce in Central Arizona
}

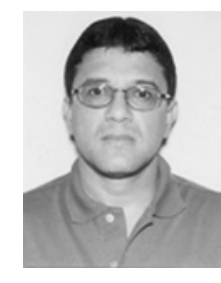

Aureo S. de Oliveira1 ${ }^{1}$ Edward C. Martin², Donald C. Slack², Edward J. Pegelow ${ }^{3} \&$ Allen D. Folta ${ }^{4}$

1 DEA/UFBA. CEP 44380-000, Cruz das Almas, BA. Fone: (75) 621-1220, Ramal: 212, E-mail: aureo@ufba.br (Foto)

2 Dept. of Agricultural \& Biosystems Engineering, University of Arizona, Shantz Bldg. Tucson, AZ, 85721, USA, Fax: (520) 568-2556. E-mail: edmartin@cals.arizona.edu; slackd@u.arizona.edu

3 The University of Arizona Maricopa Agricultural Center 37860 W. Smith-Enke Road Maricopa, Arizona 85239, USA Telephone: (520) 568-2273, Fax: (520) 568-2556.

${ }^{4}$ Fintech Precast, Inc. 16761 Clear Creek Road Redding, CA, 96001, Fone: (530) 241-8397, Fax: (530) 241-1249. E-mail: dan.folta@yahoo.com

\author{
Protocolo 123 - 15/7/2003 - Aprovado em 2/6/2004
}

\begin{abstract}
A two year field study (1996/97 and 1997/98 growing seasons) was carried out at the Maricopa Agricultural Center $\left(33^{\circ} 04^{\prime} 07^{\prime \prime} \mathrm{N}\right.$; $111^{\circ} 57^{\prime} 18^{\prime \prime} \mathrm{W}$ ) of the University of Arizona, USA, to investigate the water use and to derive $\mathrm{K}_{c}$ 's for subsurface drip-irrigated head lettuce grown in small weighable lysimeters. Measurement periods ranged from 480 to $1100{ }^{\circ} \mathrm{C}$-day (96/97) and from 439 to $1098{ }^{\circ} \mathrm{C}$-day (97/98). These intervals corresponded essentially to the second half of the crop cycle which amounted to a $1100{ }^{\circ} \mathrm{C}$-day, on average. The lysimeters were weighed periodically and the computation of the water balance revealed an average water use of $117 \mathrm{~mm}$. Basal crop $\mathrm{K}_{\mathrm{c}}$ was expressed as a function of cumulative growing degree days following a multiple linear regression procedure in which the data were fitted with a Fourier sine series model with up to six coefficients. Two-year $\mathrm{K}_{c}$ curves were obtained based on the Hargreaves, FAO Penman and FAO Penman-Monteith equations and compared to the AZSCHED (AriZona SCHEDuling) irrigation package. Predicted $\mathrm{K}_{\mathrm{c}}$ peaked $0.88,0.80$ and 0.81 with the Hargreaves, FAO Penman, FAO Penman-Monteith equations, respectively, in the range of 1000 to $1050{ }^{\circ} \mathrm{C}$ day, in contrast to AZSCHED which predicted the peak $K_{c}$ to be 1.01 at $1150{ }^{\circ} \mathrm{C}$-day.
\end{abstract}

Key words: SDI, Lactuca sativa, lysimeter, evapotranspiration

\section{Demanda hídrica e coeficiente de cultura da alface irrigada por gotejamento sub-superficial na região central do Arizona}

Resumo: Um estudo conduzido na Fazenda Experimental Maricopa (33०04'07" N; $111^{\circ} 57^{\prime} 18^{\prime \prime}$ W), pertencente à Universidade do Arizona, USA, nos anos agrícolas de 1996/97 e 1997/98, objetivou determinar o uso de água e derivar coeficientes de cultura $\left(\mathrm{K}_{\mathrm{c}}\right)$ da alface de cabeça irrigada por gotejamento subsuperficial e cultivada em lisímetros de pesagem intermitente. 0 período de medições, expresso em graus-dia acumulados, variou de 480 a $1100{ }^{\circ} \mathrm{C}$-dia em 96/97 e de 439 a $1098{ }^{\circ} \mathrm{C}$-dia em 97/98. Esses intervalos corresponderam à segunda metade do ciclo da cultura, sendo que até a colheita somou-se uma média de $1100{ }^{\circ} \mathrm{C}$-dia. Os lisímetros eram pesados periodicamente e o balanço hídrico revelou um consumo médio de $117 \mathrm{~mm}$, naqueles períodos. $\mathrm{O} \mathrm{K}_{\mathrm{c}}$ basal foi relacionado com o acúmulo de graus-dia através de regressão múltipla, seguindo um modelo dado por uma série seno de Fourier, com até seis coeficientes. As curvas de $\mathrm{K}_{\mathrm{c}}$ foram determinadas com base nos métodos de Hargreaves, FAO Penman e FAO PenmanMonteith, para cálculo da ET e comparadas por aquela gerada pelo programa AZSCHED (AriZona SCHEDuling) de manejo da irrigação. Valores máximos de $\mathrm{K}_{\mathrm{c}}$ estimados foram 0,88 (método de Hargreaves), 0,80 (FAO Penman) e 0,81 (FAO Penman-Monteith) no intervalo de 1000 a 1050 ${ }^{\circ} \mathrm{C}$ dia, inferiores a $1,01 \mathrm{em} 1150{ }^{\circ} \mathrm{C}$ dia, que é o máximo Kc previsto pelo programa AZSCHED.

Palavras-chave: SDI, Lactuca sativa, lisímetro, evapotranspiração 


\section{INTRODUCTION}

The water requirement of a given crop is represented by its evapotranspiration $\left(\mathrm{ET}_{\mathrm{c}}\right)$, basically defined as the rate of transfer of water vapor from plant and soil surfaces to atmosphere. This is a key element for the implementation of irrigation management strategies for crop production at both farm and irrigation scheme levels and for the study of leaching of agrochemicals towards ground waters. In the agricultural areas of Arizona, irrigation plays an essential role in the production of grains, cotton, fruits, alfalfa, and vegetables (Irrigation Journal, 2001). The State of Arizona is a major contributor to the nation's winter lettuce supply. Arizona also ranks near the top nationally in the production of broccoli, carrots, cauliflower and spring onions. Lettuce was grown on more hectares than any other vegetable crop in Arizona in 2000 (Irrigation Journal, 2001). Total area was 25,250 ha and corresponded to roughly $58 \%$ of the total irrigated area under vegetable production in that year.

Studies on water use by vegetable crops in Arizona have been conducted since the classical work done by Erie et al. (1965). Due to its importance as the major source of information on water requirements for many crops in the Southwestern US, the paper was later reprinted (USDA, 1982). Even today, many irrigation management schemes in Arizona and the Southwest are based on information from that report. Fox et al. (1992) incorporated the lettuce water use data from Erie et al. (1965) into the AZSCHED (AriZona SCHEDuling) irrigation program. The estimates of head lettuce ET obtained by Erie et al. (1965) were based on gravimetric measurements of soil water content in furrow-irrigated lettuce fields. They concluded that the crop seasonal water use was about $216 \mathrm{~mm}$ for a three and a half month growing season with time of planting around September 15. The peak water use was observed to occur in the head development stage and they also showed that $56 \%$ of seasonal soil moisture depletion by crop water use occurred in the top $30 \mathrm{~cm}$. More recently, Gallardo et al. (1996) and Grattan et al. (1998) have also reported lettuce water use for California conditions.
Surface irrigation is still the most widely used method for irrigating lettuce in the US. But pressurized irrigation systems like sprinkler and subsurface drip have gained a lot of importance due to their ability to achieve higher irrigation efficiency and uniformity when compared to traditional surface systems. Considering the facts related to the importance of the drip irrigation systems for crop production in arid and semiarid areas and the lack of more updated information on lettuce water use in Arizona grown under that irrigation method, a field study was conducted to determine the seasonal water use of subsurface-drip irrigated lettuce and to derive crop coefficients to be used in irrigation scheduling programs.

\section{MATERIAL AND METHODS}

\section{Site characterization}

This research was carried out at the Maricopa Agricultural Center (MAC) of the University of Arizona in the 1996/97 and 1997/98 growing seasons (Fall-Winter). Local coordinates are: latitude $33^{\circ} 04^{\prime} 07^{\prime \prime} \mathrm{N}$, longitude $111^{\circ} 57^{\prime} 18^{\prime \prime} \mathrm{W}$, and altitude 361 $\mathrm{m}$. The soil is a deep, well drained and slowly permeable alluvial; classified as Casa Grande sandy loam. Physical and chemical characteristics of the soil based on samples taken from the top $20 \mathrm{~cm}$ included $67 \%$ of sand, $19.7 \%$ of silt, $13.3 \%$ of clay, $\mathrm{pH}$ 7.9, EC $0.624 \mathrm{dS} \mathrm{m}^{-1}, \mathrm{Ca}^{+2} 8380 \mathrm{ppm}, \mathrm{Mg}^{+2} 4600 \mathrm{ppm}, \mathrm{Na}^{+} 345$ $\mathrm{ppm}, \mathrm{K}^{+} 3350 \mathrm{ppm}$. Winter temperatures range from -2 to $17^{\circ} \mathrm{C}$ and summer temperatures range from 25 to $42{ }^{\circ} \mathrm{C}$. Annual average rainfall is about $185 \mathrm{~mm}$. Averages and totals for selected weather parameters during both seasons are shown in Table 1. Data were taken from the nearest AZMET (AriZona METeorological network) weather station located $50 \mathrm{~m}$ south of the experimental area.

Most of the irrigation water used at MAC comes from the Central Arizona Project, which is primarily diverted from the Colorado River although it is often mixed with groundwater. Results from the analysis of a sample taken in 1996 revealed a $\mathrm{pH}$ of 8.1 and an $\mathrm{EC}$ of $1.11 \mathrm{dS} \mathrm{m}^{-1}$. Additional analysis revealed chemical concentrations of $72.8 \mathrm{ppm} \mathrm{Ca}^{+2}, 14.3 \mathrm{ppm} \mathrm{Mg}{ }^{+2}, 191$ ppm Na${ }^{+}, 3.85 \mathrm{ppm} \mathrm{K}^{+}$, carbonate content $<1 \mathrm{mg} \mathrm{L}^{-1}$, bicarbonate content $192 \mathrm{mg} \mathrm{L}^{-1}$ and alkalinity $157 \mathrm{mg} \mathrm{L}^{-1}$.

Table 1. Monthly average values of selected weather parameters at MAC Farm, 96/97 and 97/98 seasons

\begin{tabular}{|c|c|c|c|c|c|c|c|c|c|c|}
\hline \multirow{2}{*}{ Month } & \multicolumn{3}{|c|}{ Air Temperature $\left({ }^{\circ} \mathrm{C}\right)$} & \multicolumn{3}{|c|}{ Relative Humidity (\%) } & \multicolumn{2}{|c|}{ Solar Radiation $\left(\mathrm{MJ} \mathrm{m}^{-2}\right)$} & \multirow{2}{*}{$\begin{array}{l}\text { Rainfall** } \\
(\mathrm{mm})\end{array}$} & \multirow{2}{*}{$\begin{array}{l}\text { Wind Speed } \\
\left(\mathrm{ms}^{-1}\right)\end{array}$} \\
\hline & $\max$ & $\min$ & mean & $\max$ & $\min$ & mean & daily mean & Total & & \\
\hline Nov-96 & 24.9 & 5.4 & 14.6 & 77.9 & 19.7 & 44.9 & 13.8 & 414.7 & 2 & 1.6 \\
\hline Dec & 20.6 & 1.6 & 10.2 & 80.3 & 22.2 & 49.4 & 11.9 & 369.1 & 0 & 1.5 \\
\hline Jan-97 & 18.5 & 3.6 & 10.8 & 92.4 & 36.3 & 66.8 & 11.0 & 342.0 & 10 & 1.9 \\
\hline Feb & 21.1 & 2.5 & 11.7 & 75.8 & 18.6 & 42.8 & 16.0 & 447.8 & 4 & 2.1 \\
\hline Mar* & 23.1 & 2.2 & 12.7 & 85.8 & 15.3 & 48.0 & 21.6 & 151.1 & 0 & 1.4 \\
\hline Average & 21.7 & 3.0 & 12.0 & 82.4 & 22.4 & 50.4 & 14.9 & - & - & 1.7 \\
\hline Oct-97* & 28.4 & 5.9 & 16.2 & 76.5 & 14.3 & 43.4 & 17.5 & 35.0 & 0 & 1.1 \\
\hline Nov & 24.1 & 5.2 & 14.0 & 84.4 & 23.1 & 52.3 & 13.4 & 402.1 & 2 & 1.3 \\
\hline Dec & 16.7 & 1.4 & 8.5 & 97.2 & 36.4 & 73.4 & 11.4 & 353.1 & 28 & 1.6 \\
\hline Jan-98 & 19.3 & 2.5 & 10.3 & 94.3 & 30.3 & 67.1 & 12.7 & 394.4 & 1 & 1.3 \\
\hline Feb & 16.9 & 4.4 & 10.4 & 98.0 & 44.4 & 78.2 & 14.1 & 394.6 & 83 & 1.9 \\
\hline Mar* & 22.1 & 5.5 & 13.6 & 95.2 & 28.4 & 62.8 & 19.4 & 369.1 & 7 & 1.8 \\
\hline Average & 21.2 & 4.1 & 12.7 & 90.9 & 29.5 & 62.9 & 14.7 & - & - & 1.5 \\
\hline
\end{tabular}

"Averages and totals corresponding to part of the month only; "* Total rain depth for the period was $16 \mathrm{~mm}$ for the $1996 / 97$ season and $121 \mathrm{~mm}$ for the $1997 / 98$ season 


\section{Lysimeter design and crop management}

The experimental area consisted of six plots with four beds each. A bed shaper was used to make the beds that were roughly $15 \mathrm{~cm}$ high, $100 \mathrm{~cm}$ wide and $18.6 \mathrm{~m}$ long. Buffer beds were on the east and west side of the plot and the harvest beds were in the center. In both the $96 / 97$ and $97 / 98$ seasons, a small weighing lysimeter, as described by Martin et al. (2001), was installed in one of the harvest beds, in the center of the plot. Winter head lettuce (Lactuca sativa L.) and onion (Allium cepa L.) were sown in 1996 and lettuce and kale (Brassica oleracea L. var. acephala) were sown in 1997 but only results on lettuce from both the years are reported and discussed in this paper.

A lysimeter was comprised of an outer rectangular retaining shell and an inner tank, with an internal area of about $0.929 \mathrm{~m}^{2}$. Drainage water was suctioned by a 34-L evacuated metal tank connected to ceramic cylinders installed at the bottom of the inner tank. The lysimeter weighing equipment consisted of a four-wheel spirit sprayer chassis, a digital weighmeter, a load cell, and hook-ended chains to lift the lysimeters up. A detailed description of the lysimeter and the weighing system can be found in Martin et al. (2001). On weighing days, the sprayer was driven to the field and parked above the first lysimeter where the chains were lowered and the hooks connected to the corners of the lysimeter. The drainage tank was then disconnected and taken to the laboratory for collecting and weighing of the drainage water. Frequency of weighing varied from 1 to no more than 3 times a week and was higher in the 97/ 98 season as compared to the $96 / 97$ season.

Two rows were mechanically seeded in each bed before lysimeter installation and hand-seeded in the lysimeters after their installation. The beds were subsurface drip-irrigated for the first time on the day following the sowing in the lysimeters. Turbulent flow twin-wall drip irrigation tapes (Chapin Watermatics, Inc., USA ${ }^{1}$ ) with wall thickness of $381 \mu \mathrm{m}$, and 23 $\mathrm{cm}$ outlet space, were buried at about $15 \mathrm{~cm}$ depth at the center of each bed during bed formation. According to the manufacturer, the tape flow rate was about $373{\mathrm{~L} 100 \mathrm{~m}^{-1} \mathrm{~h}^{-1} \text { at }}$ the $68.9 \mathrm{kPa}$ pressure. These specifications were verified in a field test.

The planting date, considered to be the date of the first irrigation, was on $24^{\text {th }}$ October (DOY 298) in 1996 and $23 \mathrm{rd}$ October (DOY 296) in 1997. Emergence occurred about seven days after planting in both years, i.e., on $1^{\text {st }}$ November 1996 (DOY 306) and 30 ${ }^{\text {th }}$ October 1997 (DOY 303). Dry fertilizer was applied prior to planting to assure adequate nutrient content in the soil. An application of $560 \mathrm{~kg} \mathrm{ha}^{-1}$ of 11-55-0 was applied to the entire plot prior to any field activity. Additional nitrogen was applied using UAN-32 liquid fertilizer injected directly into the irrigation system by a differential pressure type injector. The applications were made throughout the season to match crop needs at different stages of growth. The fertilizer application rate was $26.4 \mathrm{~L} \mathrm{ha}^{-1}$ with time of application ranging from 15 to $30 \mathrm{~min}$. Since the seeds were mechanically sown, the final plant spacing was determined by thinning. The first thinning in 96/97 was made during the $3^{\text {rd }}$ week after emergence for a temporarily $8 \mathrm{~cm}$ spacing. A second thinning during the $6^{\text {th }}$

\footnotetext{
Mention of a trade name or specific equipment is only for illustration purposes and does not imply endorsement by the authors
}

week resulted in the final plant spacing of $23 \mathrm{~cm}$. In 97/98, only one thinning during the $4^{\text {th }}$ week after plant emergence was made. After thinning, four plants per row were left in each lysimeter totaling eight plants per lysimeter. In both seasons, all plots were hand-cleaned for weed control during the $5^{\text {th }}$ and $6^{\text {th }}$ weeks after plant emergence.

\section{Soil water monitoring and irrigation control}

A TDR device (model 6060X1 TRASE, Soilmoisture Corp., Goleta, CA, USA) was used to measure the soil water content in the crop root zone during both the $96 / 97$ and $97 / 98$ seasons. The TDR was calibrated against the standard gravimetric method from soil samples taken in the top $45 \mathrm{~cm}$, covering a broad range of soil moisture from dry to wet. In 97/98, soil moisture conditions were also monitored with digital tensiometers (Soil Measurement Systems, Inc., Tucson, AZ, USA) installed inside and outside the lysimeters at a depth of $45 \mathrm{~cm}$. TDR waveguide probes were installed in all three lysimeters at 15, 30 and $45 \mathrm{~cm}$ depths. At each depth, three readings were taken but only the last two were recorded. The first one was discarded as to stabilize the readings and to check for reading errors. Initially, the amount of irrigation water to apply was calculated using soil moisture data from the $30 \mathrm{~cm}$ TDR reading. This reading was used because it was assumed that the plant roots did not go beyond $30 \mathrm{~cm}$. Later in the season, the $45 \mathrm{~cm}$ TDR readings were used assuming the plant roots had reached this depth.

Irrigation water was applied in an amount to avoid plant stress and to promote potential evapotranspiration conditions inside and outside the lysimeters. The irrigation threshold was based on a maximum allowed depletion (MAD) of 35\%. TDR readings were taken inside and outside the lysimeters before each irrigation and the decision to irrigate was based on moisture data from the lysimeters. Probes were also installed in the bed outside the lysimeters. Tensiometer readings were also taken on a regular basis and always before irrigation. The maximum irrigation depth was calculated based on the root system depth and total available water between field capacity $\left(0.270 \mathrm{~cm}^{3} \mathrm{~cm}^{-3}\right)$ and permanent wilting point $\left(0.140 \mathrm{~cm}^{3} \mathrm{~cm}^{-3}\right)$. Gross irrigation depths were calculated using $95 \%$ application efficiency for the irrigation system.

\section{Water balance in the lysimeters}

The lysimeters were always weighed before irrigation, but were not always weighed right after. For those days when the lysimeters were not weighed after irrigation, the amount of water applied was estimated based on the weight variation data obtained on the days when they were weighed after irrigation. The first weighing period started on December 19, 1996 (48 days after emergence, DAE, DOY 354) and ended on March 4,1997 (123 DAE, DOY 63), a 76-day interval during which the lysimeters were weighed 13 times. In 97/98, the lysimeters were weighed 20 times from December 15, 1997 (46 DAE, DOY 349) to March 19, 1998 (140 DAE, DOY 78), a 94-day interval.

The water balance components in a lysimeter over a given period of time are irrigation, precipitation, evapotranspiration, drainage, and water storage variation. Irrigation runoff was 
null since the crop was subsurface drip irrigated. Rainfall runoff into the lysimeters was prevented through the gap between the walls of the inner and outer tanks and rainfall runoff out of the lysimeters was considered negligible, since depended on rain intensity and initial soil moisture conditions. Based on these assumptions, the water balance could be solved for ET as given by:

$$
\mathrm{ET}_{\mathrm{c}}=\frac{[(\mathrm{I}+\mathrm{P})-(\mathrm{D}+\Delta \mathrm{S})]}{\Delta \mathrm{t}}
$$

where $\mathrm{ET}_{\mathrm{c}}=$ average crop evapotranspiration $\left(\mathrm{mm} \mathrm{day}^{-1}\right), \mathrm{I}=$ irrigation depth $(\mathrm{mm}), \mathrm{P}=$ precipitation depth $(\mathrm{mm}), \mathrm{D}=$ drainage depth ( $\mathrm{mm}), \Delta \mathrm{S}=$ soil water content variation $(\mathrm{mm})$ being the difference between two consecutive weighings of the lysimeter, and $\Delta \mathrm{t}=$ time interval (day).

\section{Derivation of crop coefficient curve}

Basal crop coefficient over a given time interval $\Delta \mathrm{t}$ was calculated as follows:

$$
\mathrm{K}_{\mathrm{c}}=\frac{\mathrm{ET}_{\mathrm{c}}}{\mathrm{ET}_{\mathrm{o}}}
$$

where $\mathrm{K}_{\mathrm{c}}=$ average basal crop coefficient (dimensionless) and $\mathrm{ET}_{\mathrm{o}}=$ average reference crop evapotranspiration $\left(\mathrm{mm} \mathrm{day}^{-1}\right)$.

Cumulative growing degree-days from plant emergence, (CGDD), were used as a normalizing factor to draw the crop coefficient curve. Then, CGDD was the independent variable against which $\mathrm{K}_{\mathrm{c}}$ values could be plotted. A multiple linear regression with up to six coefficients was performed to fit the data (Fox et al., 1992; Slack et al., 1996), following:

$\mathrm{K}_{\mathrm{c}}=\mathrm{C}_{\mathrm{l}} \sin \mathrm{Y}+\mathrm{C}_{2} \sin 2 \mathrm{Y}+\mathrm{C}_{3} \sin 3 \mathrm{Y}+\mathrm{C}_{4} \sin 4 \mathrm{Y}+\mathrm{C}_{5} \sin 5 \mathrm{Y}+\mathrm{C}_{6} \sin 6 \mathrm{Y}$

where $C_{n}=$ regression coefficient. The regression analysis was performed with the constant value set to zero. The variable $\mathrm{Y}$ is obtained through:

$$
\mathrm{Y}=\pi \frac{\mathrm{CGDD}}{\mathrm{C}_{\mathrm{o}}}
$$

where $\mathrm{C}_{\mathrm{o}}$ determines the value of cumulative growing degreedays where the crop coefficient returns to zero or some minimum value. In this work, $\mathrm{C}_{\mathrm{o}}$ for lettuce was taken as $1450{ }^{\circ} \mathrm{C}$-day (Slack et al., 1996). Therefore, once the $\mathrm{C}_{n}$ values were determined, $\mathrm{K}_{\mathrm{c}}$ could be obtained for any time in the season, through Eq. 3. Growing degree-days were calculated using the sine curve method as reported by Fry (1983). Following recommendations by Slack et al. (1996), the minimum threshold temperature, $\mathrm{T}_{\mathrm{h}}$, was set to be $3.33{ }^{\circ} \mathrm{C}$ and the upper limiting temperature, $\mathrm{T}_{\mathrm{u}}$, was set to be $21.1^{\circ} \mathrm{C}$. The value of CGDD used to make a given pair (CGDD, $\mathrm{K}_{\mathrm{c}}$ ) corresponded to the average value during the time interval $\Delta \mathrm{t}(\mathrm{Eq} .1)$ and $\mathrm{K}_{\mathrm{c}}$ was obtained from Eq. 2.

Lettuce crop coefficients were calculated based on three different $\mathrm{ET}_{\mathrm{o}}$ methods, the Hargreaves equation $\left(\mathrm{ET}_{\mathrm{oH}}\right)$, the FAO
Penman equation $\left(\mathrm{ET}_{\mathrm{oFP}}\right)$, and the FAO Penman-Monteith equation $\left(\mathrm{ET}_{\mathrm{oFPM}}\right)$. The intermediate steps in the calculation of ET by each method can be found in detail in Hargreaves et al. (1985), Doorenbos \& Pruitt (1977) and Allen et al. (1994).

\section{RESULTS AND DISCUSSION}

\section{Reference ET and cumulative GDD}

The 96/97 season covered a period of 132 days from planting (October 24, 1996, DOY 298) to harvest ( March 4, 1997, DOY 63). The 97/98 season ranged from October 23, 1997 (DOY 296) to March 19, 1998 (DOY 78), totaling 148 days. Table 2 shows the seasonal and daily average $\mathrm{ET}_{\mathrm{o}}$ based on the three proposed methods.

The FAO Penman equation estimated the highest seasonal $\mathrm{ET}_{\mathrm{o}}$ in both seasons (Table 2) and also provided the highest variability in daily ET. The Penman-Monteith method has been found to perform excellent under a broad variety of conditions and several authors (Jensen et al., 1990; Beyazgül et al., 2000) have recommended it as the standard for $\mathrm{ET}_{\mathrm{o}}$ estimates. Assuming this is the case for the Central Arizona conditions, then the FAO Penman equation overestimated seasonal and daily $\mathrm{ET}_{\mathrm{o}}$ for both years. In 96/97, seasonal ET was overestimated by $6.9 \%$ and daily $\mathrm{ET}_{\text {o }}$ was overestimated by $8.3 \%$. This trend continued in $97 / 98$ with seasonal estmates $12.1 \%$ higher and daily $\mathrm{ET}_{\mathrm{o}}$ values $12.0 \%$ higher. The overestimation of the FAO Penman equation has been widely reported (Allen et al., 1989; Chiew et al., 1995) and the values found here are consistent with those abtained by.

Table 2. Seasonal and daily average ET estimates during both seasons according to the Hargreaves, FAO Penman and FAO Penman-Monteith methods

\begin{tabular}{lccccc} 
Method & \multicolumn{2}{c}{$96 / 97$ season } & & \multicolumn{2}{c}{$97 / 98$ season } \\
\cline { 2 - 3 } \cline { 5 - 6 } & $\begin{array}{c}\text { Seasonal } \\
\mathrm{ET}_{\mathrm{o}}(\mathrm{mm})\end{array}$ & $\begin{array}{c}\text { Daily average } \\
\mathrm{ET}_{\mathrm{o}}\left(\mathrm{mm} \mathrm{day}^{-1}\right)\end{array}$ & $\begin{array}{c}\text { Seasonal } \\
\mathrm{ET}_{\mathrm{o}}(\mathrm{mm})\end{array}$ & $\begin{array}{c}\text { Daily average } \\
\mathrm{ET}_{\mathrm{o}}\left(\mathrm{mm} \mathrm{day}^{-1}\right)\end{array}$ \\
\hline Iargreaves & 321 & $2.5(0.59)^{*}$ & & 353 & $2.4(0.72)$ \\
:AO P & 361 & $2.8(0.79)$ & & 379 & $2.6(0.93)$ \\
iAO PM & 336 & $2.6(0.78)$ & 338 & $2.3(0.78)$ \\
\hline
\end{tabular}

The seasonal $\mathrm{ET}_{\mathrm{o}}$ predicted by the Hargreaves equation was $4.5 \%$ lower than the FAO Penman-Monteith equation in 96/97 and 4.4\% higher than that in 97/98. In terms of daily ET,

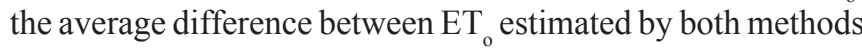
was less than $1 \%$ in $96 / 97$ and $8.0 \%$ in $97 / 98$. The $97 / 98$ season was wetter than the $96 / 97$ (Table 1) and the tendency of the Hargreaves method to overestimate ET under humid conditions has been addressed (Hargreaves, 1989; Amatya et al., 1995). Despite a near null average difference in the 96/ 97 season, the relative difference between $\mathrm{ET}_{\mathrm{oH}}$ and $\mathrm{ET}_{\mathrm{oFPM}}$ on a daily basis ranged from - 43 to $62 \%$. This scattered pattern (overpredicting, then underpredicting) exhibited by the Hargreaves equation on a daily basis was also discussed by Henggeler et al. (1996).

The summation of GDD started from the emergence date, i.e., Nov. 1, 1996 (DOY 306) and Oct. 30, 97 (DOY 303). The 
cumulative GDD was $1100{ }^{\circ} \mathrm{C}$-day by the end of the $96 / 97$ season and about $1170{ }^{\circ} \mathrm{C}$-day in the $97 / 98$ season.

\section{Irrigation scheduling and soil moisture profiles}

TDR readings inside the lysimeters were used to determine when to irrigate. The gross amount of water to be applied was then determined using an application efficiency of $95 \%$. At the study site, a timer was set for the calculated irrigation time. Irrigation depths were initially calculated for the $30 \mathrm{~cm}$ depth but in the last quarter of both seasons, when the plants reached their stage of peak vegetative development, calculations were made using a rooting depth of $45 \mathrm{~cm}$. The soil water depletion inside and outside the lysimeters is summarized in Table 3 . The average soil water depletion at both the 30 and $45 \mathrm{~cm}$ depths in the lysimeters was lower than the maximum allowed value of $35 \%$.

Table 3. Average and maximum soil water depletion inside and outside the lysimeters during the growing seasons

\begin{tabular}{|c|c|c|c|c|}
\hline \multirow{3}{*}{$\begin{array}{l}\text { Relative } \\
\text { Position }\end{array}$} & \multicolumn{4}{|c|}{ Depletion (\%) } \\
\hline & \multicolumn{2}{|c|}{$96 / 97$} & \multicolumn{2}{|c|}{$97 / 98$} \\
\hline & $0-30(\mathrm{~cm})$ & $0-45(\mathrm{~cm})$ & $0-30(\mathrm{~cm})$ & $0-45(\mathrm{~cm})$ \\
\hline Inside & $29.5(43.1)^{*}$ & $16.7(31.5)$ & $28.6(35.4)$ & $16.5(23.1)$ \\
\hline Outside & $45.6(60.0)$ & $44.2(56.2)$ & $50.5(62.3)$ & $42.6(52.3)$ \\
\hline
\end{tabular}

In general, the soil water depletion outside the lysimeters was higher than inside. The depletion was also higher at the 30 $\mathrm{cm}$ depth compared to the $45 \mathrm{~cm}$ depth, in both inside and outside the lysimeters. The variation of soil water depletion in 96/97 and 97/98 is shown in Figure 1A and Figure 1B. Most of the readings were taken prior to irrigation on the days when the lysimeter was weighed and therefore, on those days, the depletion was well above zero.

Higher soil water depletion levels were measured both inside and outside the lysimeters in the top $30 \mathrm{~cm}$, suggesting that the plants extracted more water from this depth where root density would be higher. According to Nonnecke (1989), lettuce forms a deep, penetrating taproot, but the major absorbing root area is found spreading laterally in the upper $30 \mathrm{~cm}$ of the soil. No investigation was done on the root system development inside the lysimeters since the lysimeter area was small and soil disturbance and plant damage were likely to occur, altering the rate of water loss as vapor.

Measurements of the soil water potential in the $97 / 98$ season at $45 \mathrm{~cm}$ gave support to the findings on soil water depletion in and out of the lysimeters, in the sense that the soil inside the lysimeters was wetter than outside. The soil water potential averaged -9.84 and $-11.06 \mathrm{kPa}$ inside and outside the lysimeters, respectively. Therefore, the soil water content at 45 $\mathrm{cm}$ was higher than the critical soil water potential $-40 \mathrm{kPa}$, which is the value that has been recommended for irrigation scheduling (Gallardo et al., 1996).

The differences in soil moisture in and out of the lysimeters, especially at lesser depths seem to go against the representativeness of the lysimeters. A vacuum drainage system was used, which is essential (Howell et al., 1991) with shallow lysimeters (depth $<1.5 \mathrm{~m}$ ) in order to get representative field conditions, since the vacuum drainage helps to equalize the
A.

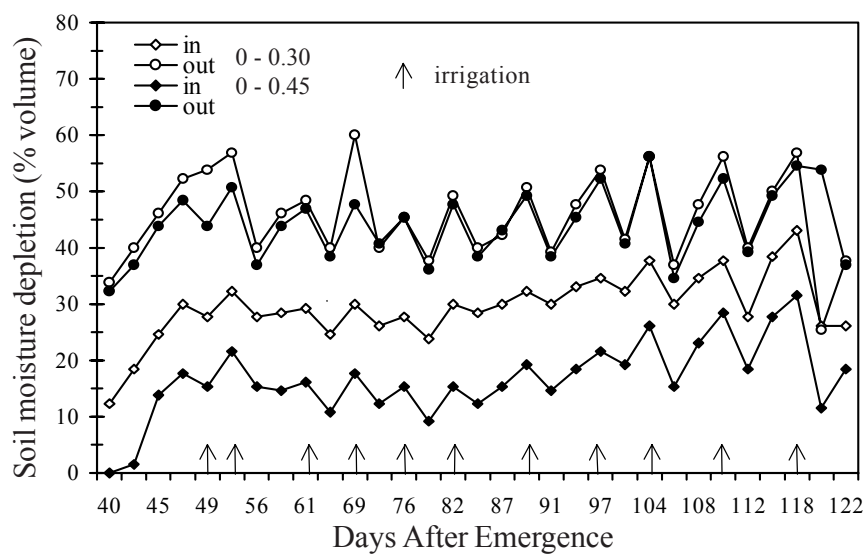

B.

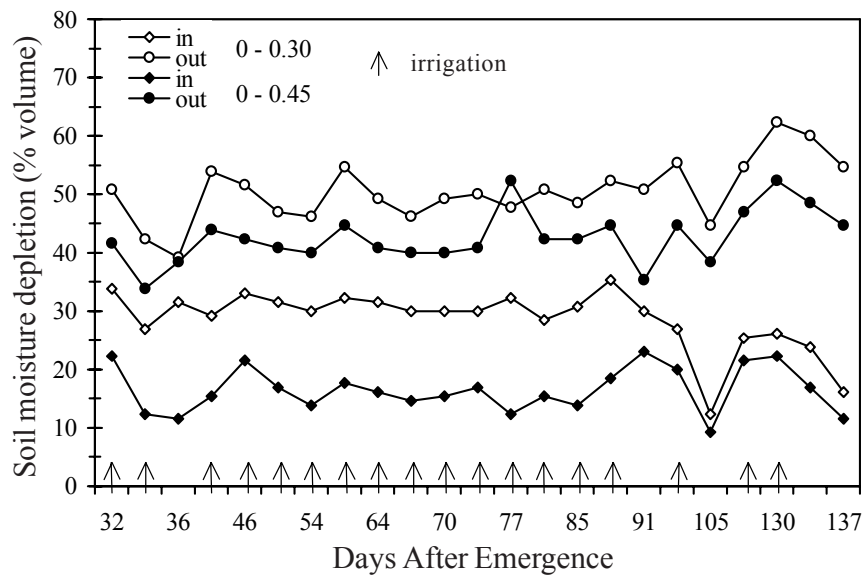

Figure 1. Average soil water depletion inside and outside the lysimeters from 40 to 122 days after emergence (DAE) during the $96 / 97$ season (A) and from 32 to 137 DAE during the 97/ 98 season (B)

water potential at the lower boundary to that in the surrounding soil. Allen et al. (1991), on the other hand, pointed out that frequently, vacuum extraction systems are only partially effective in drying lysimeter profiles and may fail with age, resulting in lysimeter profiles more moist than surrounding soils. Vaccum-leaking problems found with the drainage system used in both seasons, may have affected the ability of the drainage system in suctioning water efficiently from the lysimeter.

\section{Water applied and lettuce ET}

Lettuce ET was obtained by applying Eq. 1 to data from each of the lysimeters during the period of measurement; given in terms of CGDD. Table 4 shows the average lettuce ET and other components of the water balance in the lysimeters. The difference in the drainage depth between the seasons may in part be due to the leaks but most was due to the additional 77 mm of rainfall that occurred.

As previously shown, the weighing period corresponded to 75 days in $96 / 97$ and 87 days in $97 / 98$, in contrast to the duration of the total crop cycle which was 132 days in 96/97 and 148 days in 97/98. Therefore, the numbers in Table 4 do not tell much in terms of seasonal water use (planting to harvest) because they correspond approximately to the second half of 
Table 4. Average values of some of the components of the water balance in the lysimeters

\begin{tabular}{cccccc}
$\begin{array}{c}\text { Crop } \\
\text { Season }\end{array}$ & $\begin{array}{c}\text { Lysimeter Weighing } \\
\left.\text { Period* }{ }^{\circ} \mathrm{C} \text {-day }\right)\end{array}$ & $\begin{array}{c}\text { Irrigation } \\
(\mathrm{mm})\end{array}$ & $\begin{array}{c}\text { Rain } \\
(\mathrm{mm})\end{array}$ & $\begin{array}{c}\text { Drainage } \\
(\mathrm{mm})\end{array}$ & $\begin{array}{c}\text { Lettuce ET } \\
(\mathrm{mm})\end{array}$ \\
$\begin{array}{c}480-1100 \\
(48-123 \mathrm{DAE})\end{array}$ & 94 & 14 & 19 & 100 \\
$97 / 98$ & $\begin{array}{c}439-1098 \\
(46-133 \mathrm{DAE})\end{array}$ & 114 & 91 & 86 & 134 \\
\hline * DAE - Days after emergence & & & &
\end{tabular}

the crop cycle. These data show the water use during the most sensitive period of the crop, i.e., the head development and maturity (Shih \& Rahi, 1984). According to Swiader et al. (1992) lettuce produces approximately $70 \%$ of its total growth in the 3 weeks preceding maturity. Therefore, the bulk of the crop water use should occur during that short period. Lettuce is harvested during the maximum vegetative growth stage (Plaut \& Meiri, 1994) when the canopy covers a large part of the soil surface and ET rates are high.

Lettuce ET has been reported to vary with location, time of the year, cultivar and irrigation system. In Mesa, Arizona, Erie et al.(1965) reported a $216 \mathrm{~mm}$ water use for furrow-irrigated lettuce from planting to harvest, with planting date by the second week of September. In a study by Gallardo et al. (1996) in California, the ET of three well-watered sprinkler-irrigated lettuce cultivars varied from 141 to $153 \mathrm{~mm}$.

\section{Lettuce $K_{c}$ curve}

Lettuce basal $\mathrm{K}_{\mathrm{c}}$ was obtained by dividing average values of $\mathrm{ET}_{\mathrm{c}}$ and $\mathrm{ET}_{\mathrm{o}}$ over the respective time interval (Eq. 2). As mentioned earlier, ET ${ }_{0}$ was calculated based on the Hargreaves, FAO Penman and FAO Penman-Monteith methods. Crop coefficient values from both $96 / 97$ and 97/98 seasons were combined and resulted in the regression equation coefficients shown in Table 5.

The coefficients of the regression model used by AZSCHED (Fox et al., 1992) to estimate lettuce $\mathrm{K}_{\mathrm{c}}$ are shown here for comparison purposes. These coefficients were derived from data reported by Erie et al. (1982). AZSCHED used a Penman-type equation to estimate ET. A graphical representation of the models in Table 5 is shown in Figure 2.

The first three models in Table 5 are not recommended for estimating $\mathrm{K}_{\mathrm{c}}$ values between the planting date and about 450 ${ }^{\circ} \mathrm{C}$ day, since no experimental data were available to define the shape of the curve in that range. For irrigation scheduling purposes, $\mathrm{K}_{\mathrm{c}}$ values in that range can be estimated from a single straight-line as shown in Figure 2 for the AZSCHED-

Table 5. Multiple linear regression coefficients to estimate lettuce $\mathrm{K}_{\mathrm{c}}$ based on the Hargreaves (HARG), FAO Penman (FAOP), and FAO Penman-Monteith (FAOPM) methods $(\mathrm{N}=27)$, and AZSCHED

\begin{tabular}{lccccccc}
\hline ET $_{0}$ Method & $\mathrm{C}_{1}$ & $\mathrm{C}_{2}$ & $\mathrm{C}_{3}$ & $\mathrm{C}_{4}$ & $\mathrm{C}_{5}$ & $\mathrm{C}_{6}$ & $\mathrm{R}^{2}$ \\
HARG & 0.617 & -0.368 & 0.009 & -0.063 & -0.070 & - & 0.73 \\
FAOP & 0.698 & -0.148 & 0.226 & 0.087 & 0.068 & 0.042 & 0.65 \\
FAOPM & 0.653 & -0.263 & 0.060 & -0.018 & -0.024 & - & 0.60 \\
AZSCHED & 0.677 & -0.368 & 0.202 & -0.119 & 0.030 & - & - \\
\hline
\end{tabular}

based $\mathrm{K}_{\mathrm{c}}$ or a different approach can be used to estimate crop water demand.

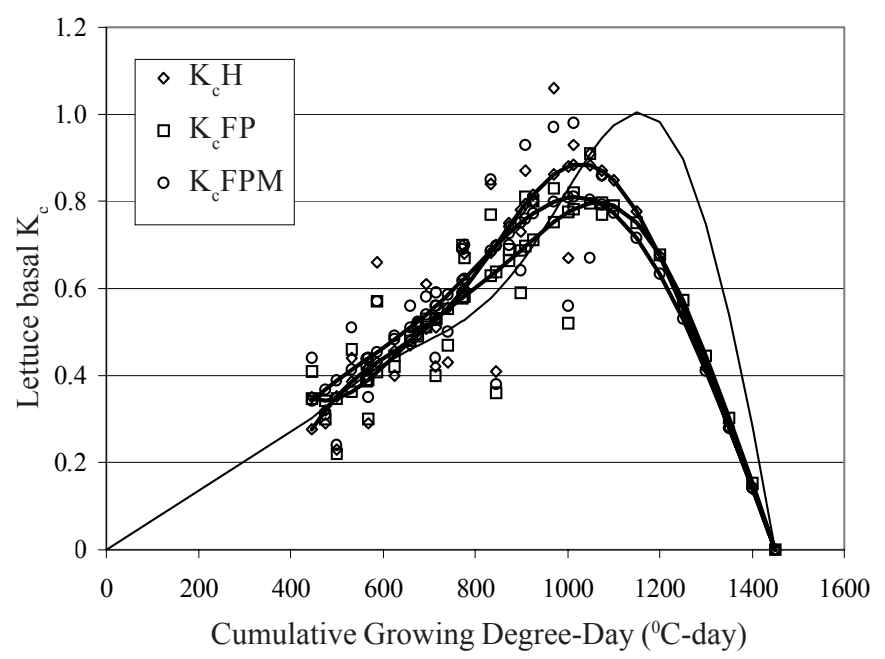

Figure 2.Observed and predicted lettuce basal $\mathrm{K}_{\mathrm{c}}$ based on the three $\mathrm{ET}_{\mathrm{o}}$ methods and the $\mathrm{K}_{\mathrm{c}}$ values predicted by the AZSCHED software

The lettuce $\mathrm{K}_{\mathrm{c}}$ predicted by all three $\mathrm{ET}_{\mathrm{o}}$ methods was about the same, with small differences in the 450 to $800^{\circ} \mathrm{C}$ day range, when started to differentiate toward the peak values. The Hargreaves based $\mathrm{K}_{c}$ peaked 0.88 while FAO Penman and FAO Penman-Monteith based $\mathrm{K}_{\mathrm{c}}$ peaked 0.80 and 0.81 , respectively, between 1000 and $1050^{\circ} \mathrm{C}$-day. The AZSCHED lettuce $\mathrm{K}_{c}$ peaked 1.01 at about $1150{ }^{\circ} \mathrm{C}$-day. It is seen that the experimental $\mathrm{K}_{c}$ curves shifted downwards and to the left with respect to the AZSCHED $\mathrm{K}_{\mathrm{c}}$ curve, regardless the $\mathrm{ET}_{\mathrm{o}}$ method used.

Lettuce crop coefficients have been reported, however, in most cases, the type of lettuce used (leafy or head) is not clearly mentioned or is not specified. Information on crop management and irrigation methods is also frequently absent. Most $\mathrm{K}_{\mathrm{c}}$ values are arranged in tables and are a function of time (Julian days or days after planting or emergence). Few studies used heat units as a normalizing variable. The use of percentage ground cover has only recently been reported (Grattan et al., 1998).

Other authors have reported different values of $\mathrm{K}_{\mathrm{c}}$ for lettuce and according to Doorenbos \& Pruitt (1977), the minimum and maximum suggested $\mathrm{K}_{\mathrm{c}}$ values were 0.25 and 1.00 . For a wellwatered lettuce field, Gallardo et al. (1996) in California found maximum $\mathrm{K}_{\mathrm{c}}$ to vary from 0.81 to 1.02 by harvest. In that study, $\mathrm{ET}_{\mathrm{o}}$ was obtained from the CIMIS network and $\mathrm{K}_{\mathrm{c}}$ was expressed as a fuction of time (DAE). Hargreaves \& Samani (1991) reported lettuce $\mathrm{K}_{\mathrm{c}}$ values based on a reference ET calculated using the Hargreaves equation. They reported peak $\mathrm{K}_{\mathrm{c}}$ to vary from 0.85 to 1.05 . In the present study, the predicted peak $\mathrm{K}_{\mathrm{c}}$ using the Hargreaves ET oquation was 0.88. Snyder \& Pruitt (1989) presented two sets of lettuce $\mathrm{K}_{\mathrm{c}}$ for California conditions depending on the planting date, i.e., end of August and end of October, according to the straight-line approach of Doorenbos $\&$ Pruitt (1977). For the first planting date, they recommended 0.17 (10\% ground cover), 1.02 (peak canopy development), and 0.10 (end of the season). The corresponding $\mathrm{K}_{\mathrm{c}}$ values for the 
second planting date were $0.30,0.87$, and 0.30 . Grattan et al. (1998) recently reported $\mathrm{K}_{\mathrm{c}}$ polynomial models for furrowirrigated iceberg lettuce and other vegetable (row) crops, applying the percentage of canopy cover as the independent variable. They used data from two locations in California (El Centro and Imperial Valley). Lettuce ET was measured from 2.5 to $71 \%$ of ground cover. The fitted curve was a second-order polynomial and the predicted $\mathrm{K}_{\mathrm{c}}$ values varied from 0.1 to about 0.78 .

\section{CONCLUSIONS}

1. The water use of subsurface drip-irrigated lettuce indicate an average demand of $117 \mathrm{~mm}$.

2. This amount basically reflects the water demand during the second half of the crop cycle that accumulated $1100{ }^{\circ} \mathrm{C}$-day, on the average.

3. Crop coefficients based on Hargreaves, FAO Penman and FAO Pernman-Monteith peaked $0.88,0.80$ and 0.81 , respectively in the range of 1000 to $1050{ }^{\circ} \mathrm{C}$-day.

4. These values were lower than and occurred earlier than the maximum $\mathrm{K}_{\mathrm{c}}$ predicted by the AZSCHED irrigationscheduling model.

\section{ACKNOWLEDGMENTS}

The first author would like to thank the Brazilian Ministry of Education through CAPES, which supported him to pursue his $\mathrm{PhD}$ at the University of Arizona, Tucson, AZ, USA.

\section{LITERATURE CITED}

Allen, R.G.; Jensen, M.E.; Wright, J.L.; Burman, R.D. Operational estimates of evapotranspiration. Agronomy Journal, Madison, v.81, p.650-662, 1989.

Allen, R.G.; Pruitt, W.O.; Jensen, M.E. Environmental requirements for lysimeters. In: Lysimeters for evapotranspiration and environmental measurements, 2325 July, 1991, Honolulu, HI, USA. Proceedings... New York: ASCE, 1991.p.170-181.

Allen, R.G.; Smith, M.; Perrier, A.; Pereira, L.S. An update for the definition of reference evapotranspiration. ICID Bulletin, New Delhi, v.43, n.2, p.1-34, 1994.

Amatya, D.M.; Skaggs, R.W.; Gregory, J.D. Comparison of methods for estimating REF-ET. Journal of Irrigation and Drainage Engineering, New York, v.121, n.6, p.427-435, 1995.

Beyazgül, M.; Kayam, Y.; Engelsman, F. Estimation methods for crop water requirements in the Gediz Basin of Western Turkey. Journal of Hydrology, Amsterdam, v.229, p.19-26, 2000.

Chiew, F.H.S.; Kamaladasa, N.N.; Malano, H.N.; McMahon, T.A. Penman-Monteith, FAO-24 reference crop evapotranspiration and class-A pan data in Australia. Agricultural Water Management, Amsterdam, v.28, p.9-21, 1995.

Doorenbos, J.; Pruitt, W.O. Crop water requirements. Rome: FAO, 1977. 144p. Irrigation and Drainage Paper 24
Erie, L.J.; French, O.F.; Harris, K., Consumptive use of water by crops in Arizona. Tucson: The University of Arizona, Agricultural Experiment Station Technical Bulletin No. 169. 1965. 46p

Fox, A.F.; Scherer, T.; Slack, D.C.; Clark, L.J. AZSCHED-Arizona irrigation scheduling: user's manual v. 1.01. Tucson, Agricultural and Biosystems Engineering Department, The University of Arizona, 1992.36p

Fry, K.E. Heat-unit calculations in cotton crop and insect models. USDA-ARS, Advances in Agricultural Technology, Fresno, Western Series 23. 1983. 30p.

Gallardo, M.; Jackson, L.E.; Schulbach, K.; Snyder, R.L.; Thompson, R.B.; Wyland, L.J. Production and water use in lettuces under variable water supply. Irrigation Science, Heidelberg, v.16, p.125-137, 1996.

Grattan, S.R.; Bowers, W.; Dong, A.; Snyder, R.L.; Carroll, J.J.; George, W. New crop coefficients estimate water use of vegetables, row crops. California Agriculture, Berkeley, v.52, n.1, p.16-21, 1998.

Hargreaves, G. H. Accuracy of estimated reference crop evapotranspiration. Journal of Irrigation and Drainage Engineering, New York, v.115, n.6, p.1000-1007, 1989.

Hargreaves, G. H.; Samani, Z.A. Irrigation scheduling/ programacion del riego. Las Cruces: Editts, 1991. 46 p.

Hargreaves, L.G.; Hargreaves, G. H.; Riley, J.P. Irrigation water requirements for Senegal River Basin. Journal of Irrigation and Drainage Engineering, New York, v.111, n.3, p. 265-275, 1985.

Henggeler, J.C.; Samani, Z.; Flynn, M.S.; Zeitler, J.W. Evaluation of various evapotranspiration equations for Texas and New Mexico. In: International Conference on Evapotranspiration and Irrigation Scheduling, 1996, San Antonio, TX, Proceedings... St. Joseph: ASAE, 1996. p. 962-967.

Howell, T.A.; Schneider, A.D.; Jensen, M.E. History of lysimeter design and use for evapotranspiration measurements. In: Lysimeters for evapotranspiration and environmental measurements, 23-25 July, 1991, Honolulu, Proceedings... New York: ASCE, 1991.p.1-9.

Irrigation Journal. 2000 Annual irrigation survey continuous steady growth. Irrigation Journal, Heidelberg, v.51, n.1, p.1241, 2001.

Jensen, M.E.; Burman, R.D.; Allen, R.G. Evapotranspiration and irrigation water requirements. New York: ASCE, . 1990. 332p. Manuals and Reports on Engineering Practices 70

Martin, E.C.; Oliveira, A.S.; Folta, A.D.; Pegelow, E.J.; Slack, D.C. Development and testing of a small weighable lysimeter system to assess water use by shallow-rooted crops. Transactions of the ASAE, St. Joseph, v.44, n.1, p.71-78, 2001.

Nonnecke, I.L. Vegetable production. New York: van Nostrand Reinhold, 1989.657p.

Plaut, Z.; Meiri, A. Crop irrigation. In: Tanji, K.K.; Yaron, B. (eds.). Management of water use in agriculture. New York: Springer-Verlag, 1994. 320 p. Advanced Series in Agricultural Sciences 22

Shih, S.F.; Rahi, G.S. Evapotranspiration of lettuce in relation to water table depth. Transactions of the ASAE, St. Joseph, v.27, p.1074-1080, 1984. 
Slack, D.C.; Martin, E.C.; Sheta, A.E.; Fox Jr., F.; Clark, L.J.; Ashley, R.O. Crop coefficients normalized for climatic variability with growing-degree-days. In: International Conference on Evapotranspiration and Irrigation Scheduling, 1996, San Antonio. Proceedings... St. Joseph: ASAE, 1996. p.892-898.

Snyder, R.L.; Pruitt, W.O. Reference evapotranspiration. In: Goldhamer, D.A., Snyder, R.L. (eds.). Irrigation efficiency: A guide for efficient on-farm water management. Davis: ANR 1989. 67p. Publication no. 21454
Swiader, J.M.; Ware, G.W.; McCollum, J.P. Producing vegetable crops. 4ed. Danville: Interstate Publishers, 1992. 626p.

USDA - United States Department of Agriculture. Consumptive use of water by major crops in the Southwestern United States. 1982. 42p. Conservation Research Report, Phoenix, No. 29

van Bavel, C.H.M. Lysimetric measurements of evapotranspiration rates in Eastern United States. Soil Science Society of America Proceedings, Madison, v.25, p.138-141, 1961. 